\title{
PENGEMBANGAN METODE PENANDA ISOZIM PADA TREMBESI
}

\author{
Development of raintree's isozyme marker methods
}

\author{
Titis Hutama Syah ${ }^{1}$, dan Arbain ${ }^{2}$ \\ ${ }^{1}$ Kontributor Utama, ${ }^{1}, 2$ Sekolah Tinggi Pertanian Kutai Timur \\ Jl. Soekarno-Hatta, Sangatta Utara, Kutai Timur, Kalimantan Timur, Indonesia \\ email penulis korespondensi : titis@ stiperkutim.ac.id
}

Tanggal diterima: 03 Oktober 2020, Tanggal direvisi: 03 Oktober 2020, Disetujui terbit: 25 Desember 2020

\begin{abstract}
Fifty samples of raintree from Sangatta, the capital city of Kutai Timur Regency, East Kalimantan were analyzed using isozyme markers to determine the characteristics of the banding pattern. The use of isozymes was intended as a biochemical marker for genetic diversity analysis. This study aimed to determine the enzyme system that could be used to determine genetic diversity of raintree. The enzyme systems used were Diaphorase, Esterase, and Peroxidase. Polymorphism assessments were carried out on the parameters of expected heterozygosity $(H)$, polymorphism information content $(P I C)$, effective multiplex ratio $(E)$, marker index $(M I)$, discriminanting power $(D)$, and Resolving $(R)$. Among the three enzyme systems used, Diaphorase showed consistent performance against each of the parameters assessed, with a value of $H=0.475 ; P I C=0.362 ; E=$ 6.1; $M I=2,2 ; D=0.63$ : and $R=4.44$. However, Esterase had the highest multiplex effective ratio $(E=6.16)$. Therefore, Diaphorase is the best isozyme marker that can be used to analyze the genetic diversity of raintree.
\end{abstract}

Keywords: biochemical marker analysis, genetic diversity, isozyme performance, polymorphism profile, less concern raintree

\begin{abstract}
ABSTRAK
Sebanyak lima puluh sampel pohon trembesi dari Sangatta, Ibukota Kabupaten Kutai Timur, Kalimantan Timur dianalisa menggunakan penanda isozim untuk mengetahui karakteristik pola pitanya. Penggunaan isozim dimaksudkan sebagai penanda biokimia untuk analisis keragaman genetik. Tujuan dari penelitian ini adalah untuk mengetahui sistem enzim yang dapat digunakan untuk mengetahui keragaman genetik trembesi. Sistem enzim yang digunakan adalah Diaphorase, Esterase, dan Peroxidase. Penilaian-penilaian polimorfisme dilakukan terhadap parameter heterosigositas harapan $(\mathrm{H})$, informasi konten polimorfik (PIC), rasio efektif multiplek (E), indeks penanda (MI), daya diskriminan (D), dan daya bagi (R). Diantara ketiga sistem enzim yang digunakan, Diaphorase menunjukkan performa yang konsisten terhadap setiap parameter yang dinilai, dengan nilai $\mathrm{H}=0,475 ; \mathrm{PIC}=0,362 ; \mathrm{E}=6,1 ; \mathrm{MI}=2,2 ; \mathrm{D}=0,63$ : dan $\mathrm{R}=4,44$. Meskipun demikian, Esterase memiliki nilai rasio efektif multiplek tertinggi $(\mathrm{E}=6,16)$. Oleh karena itu, Diaphorase merupakan penanda isozim terbaik yang dapat digunakan untuk menganalisa keragaman genetik trembesi.
\end{abstract}

Kata kunci: analisis penanda biokimia, keragaman genetik, kinerja isozim, profil polimorfism, trembesi yang terabaikan

\section{PENDAHULUAN}

Penggunaan trembesi sebagai tanaman di kawasan perkotaan, khususnya di lahan-lahan kosong, mulai meningkat semenjak dianjurkannya jenis ini oleh Presiden Republik Indonesia dalam rangkaian gerakan menanam dan memelihara pohon pada tahun 2010 (Kementerian Sekretariat Negara Republik Indonesia, 2010). Seiring waktu, pohon tersebut kini telah tumbuh dan berkembang serta diperoleh manfaatnya. Saat ini, jenis ini banyak dijumpai sebagai tanaman tepi jalan, serta peneduh di halaman perkantoran, sekolahan maupun tempat-tempat terbuka. Bentuk tajuknya yang khas menjadikan pohon ini mudah dikenali.

Trembesi dikenal juga dengan nama ki hujan atau rain tree, dengan nama latin Samanea saman (Jacquin) Merrill termasuk dalam famili Fabaceae (Staples \& Elevitch, 2006). Trembesi dikenal sebagai pengikat nitrogen yang dapat tumbuh dengan cepat dan baik pada berbagai kondisi lingkungan. Jenis ini 
juga merupakan penyerap karbon di udara dengan sangat baik $(28.488,39 \mathrm{~kg} /$ tahun $)$ (Dahlan, 2008). Di Indonesia, trembesi merupakan jenis introduksi, bukan merupakan jenis asli. CABI (2016) menyatakan trembesi berasal dari benua Amerika dan mulai dikenal di Indonesia pada tahun 1870-an. Meskipun telah lama ditanam dan telah beradaptasi dengan baik di wilayah Indonesia, trembesi masih menyimpan potensi sebagai tumbuhan invasif yang dapat menggeser keberadaan jenis-jenis asli.

Literatur-literatur yang membahas tentang genetika trembesi masih sangat terbatas (CABI, 2016; Staples \& Elevitch, 2006). Berdasarkan analisis isozim Syah \& Arbain (2017) menyatakan keragaman genetik trembesi tergolong tinggi ( $\mathrm{HO}=0,462 ; \mathrm{HE}=0,480)$. Penanda isozim dikenal sebagai bentuk enzim yang memiliki perbedaan molekul (Markert \& Moller, 1959). Isozim telah banyak digunakan untuk penelitian-penelitian di bidang biologi, diantaranya untuk mempelajari genetika populasi, studi filogenetik, dan juga untuk memperkirakan variabilitas genetik dan taksonomi. Keunggulan penggunaan penanda isozim di antaranya adalah biayanya yang lebih murah dibandingkan dengan penggunaan penanda molekuler dan sudah banyak di aplikasikan untuk analisis genetik berbagai jenis pohon (Sulkowska, 2012).

Tujuan penelitian ini adalah untuk untuk mengetahui sistem enzim yang dapat digunakan untuk mengetahui keragaman genetik trembesi. Hasil penelitian ini diharapkan dapat memperkaya khasanah ilmu pengetahuan dalam penggunaan isozim sebagai penanda untuk analisis keragaman genetik, khususnya pada jenis trembesi.

\section{BAHAN DAN METODE}

\section{A. Waktu, bahan dan alat}

Penelitian berjalan dalam kurun waktu bulan Agustus - Oktober 2017. Sampel diambil dari pohon trembesi yang ada di Kota Sangatta,
Ibukota Kabupaten Kutai Timur, Kalimantan Timur. Sampel yang diambil berupa daun muda dari 50 pohon yang dipilih secara acak. Daun dipetik pada rentang waktu kurang dari 4 jam dan didinginkan dalam kotak es untuk mencegah daun menjadi layu dan kering, mengingat bahwa analisis isozim membutuhkan materi uji yang segar. Selanjutnya, sampel dikirim ke Laboratorium Pemuliaan Pohon, Fakultas Kehutanan, Universitas Gadjah Mada Yogyakarta untuk dianalisis.

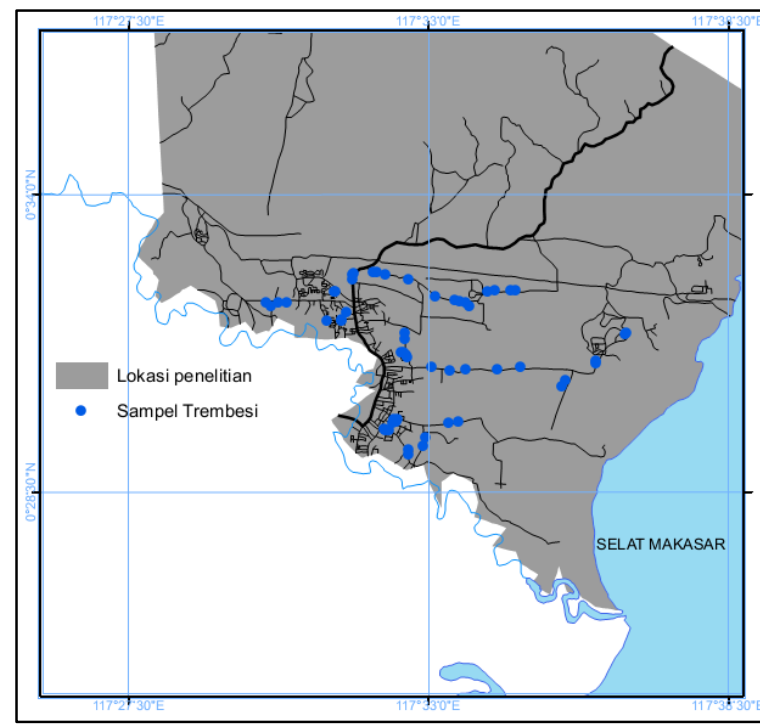

Gambar 1. Lokasi penelitian di Sangatta, Kabupaten Kutai Timur, Kalimantan Timur

\section{B. Metode}

Ekstraksi enzim dilakukan pada daun trembesi yang masih terjaga kesegarannya. Ekstraksi dimaksudkan untuk memisahkan molekul protein dengan subtrat yang lainnya berdasarkan perbedaan massa jenis-nya. Ekstraksi dilakukan menggunakan mesin refrigerated centrifuge dengan kecepatan putar $15.000 \mathrm{rpm}$, pada suhu $0^{\circ} \mathrm{C}$. Bahan yang diperlukan untuk proses ekstraksi antara lain adalah $1 \mathrm{M}$ Tris-HCL (pH 7,5), gliserol, Tween 80, ditiothreitol, dan polyvinyl-polypyrolidone yang dilarutkan dalam aquades. Enzim yang digunakan dalam penelitian ini adalah Esterase (EST; EC.3.1.1.), Peroxidase (POD; EC.1.11.1.7), dan Diaphorase (DIA; E.C.1.6.4.3).

Tahapan berikutnya adalah pembuatan gel agarose yang terdiri dari Trizma base $1 \mathrm{~N}$ 
HCL, bis-acrylamide, dan ammonium persulfate. Larutan hasil ekstraksi disuntikan ke dalam sumur-sumur (well) pada gel agarose yang sudah tercetak. Selanjutnya dilakukan proses elektroforesis menggunakan larutan buffer yang terdiri dari Trizma base dan glycine. Elektroforesis dijalankan pada suhu $\pm 7^{\circ} \mathrm{C}$ pada arus listrik sebesar $100 \mathrm{~mA}$ selama kurang lebih 3 jam. Selanjutnya dilakukan pewarnaan dan pengeringan gel. Pewarnaan dilakukan berdasarkan enzim yang diamati. Untuk memunculkan warna dilakukan penggojogan gel dan pemunculan warna dilakukan berdasarkan sistem enzim yang digunakan, yaitu: EST, POD, dan DIA. Untuk pewarnaan EST diperlukan NaH2PO4.H2O dan Na2HPO4 sebagai bahan larutan buffer, serta $\alpha$-naphtyl propionate, $\alpha$ naphtyl acetate, dan fast blue RR salt sebagai sistem enzim pewarna. Untuk POD membutuhkan Trizma base dan acetic acid glacial sebagai larutan buffer, dan pewarnaan enzimnya membutuhkan amino ethyl carboxyl, $\beta$-naphtol, acetone, dan $\mathrm{H}_{2} \mathrm{O}_{2}$. Untuk DIA membutuhkan larutan Trizma base $\mathrm{HCl}$, polyvinylpyrrolidone, dichlorophenol indophenol, $\quad \beta$-nicotinamide adenine dinucleoitide, dan tetrazolium thiazolyl blue. Untuk mengikat warna pada gel dilakukan fiksasi menggunakan alkohol.

\section{Analisis data}

Gel dinilai secara visual dengan lampu ultra violet (UV). Seluruh pola pita diamati dan digunakan untuk menyusun zymogram. Zymogram disusun berdasarkan nilai Rf, yaitu perbandingan jarak tempuh pola pita pada permukaan gel dengan jarak tempuh penanda Bromophenol Blue saat elektroforesis. Nilai Rf dicari dengan persamaan:

$$
R f=\frac{\text { jarak tempuh pola pita }}{\text { Jarak tempuh Bromophenol Blue }}
$$

Profil isozim disusun berdasarkan jumlah pola pita yang terbentuk pada setiap sistem enzim, banyaknya pola pita polimorfik, heterosigositas harapan (expected
heterozigosity/H), nilai informasi konten polimorfik (polymorphism information content/PIC), rasio efektif multiplek (effective multiplex ratio/E), indeks penanda (marker index/MI), daya diskriminan (discriminating power/D) dan daya bagi (resolving power/R). Heterosigositas harapan adalah probabilitas suatu individu bersifat heterosigot di dalam suatu populasi. Persamaan yang digunakan adalah:

$$
H=1-\sum p_{i}^{2}
$$

$p_{i}^{2}$ adalah frekuensi alel untuk alel ke- $i$, dan penjumlahannya meliputi semua alel yang ada

Informasi konten polimorfik (polymorphism Information content/PIC) adalah besarnya kemungkinan alel-alel heterosigot yang diturunkan induk ke anaknya berkurang frekuensinya. PIC juga diartikan sebagai nilai yang menunjukkan kemampuan penanda dalam membedakan pola pita yang terbentuk. Persamaannya adalah:

$$
\text { PIC }=1-\sum p_{i}^{2}-\sum \sum p_{i}^{2} p_{j}^{2}
$$

$p_{i}^{2}$ dan $p_{j}^{2}$ adalah frekuensi populasi dari alel ke- $i$ dan ke- $j$ dan $i \neq j$.

Rasio efektif multiplek (effective multiplex ratio/E) adalah jumlah lokus yang dianalisis pada zona lokus polimorfik.

$$
E=n \beta
$$

dengan $\beta=n_{p} /\left(n_{p}+n_{n p}\right), \quad \mathrm{p}$ dan $\mathrm{n}$ menunjukkan fraksi polimorfik dan nonpolimorfik, $n_{p}$ dan $n_{n p}$ menunjukkan jumlah masing-masing.

Indeks penanda (marker index/MI) adalah perkalian dari PIC dan rasio efektif multipleks, merupakan parameter statistik yang digunakan untuk memperkirakan tingkat kegunaan suatu penanda. Semakin tinggi nilai MI, semakin baik metode yang digunakan (Chesnokov \& Artemyeva, 2015). Indeks penanda juga dapat digunakan sebagai ukuran dalam menentukan efisiensi suatu penanda:

$$
M I=P I C x E
$$


Daya diskriminan (discriminating power/D) adalah probabilitas dua individu yang dipilih secara acak menunjukkan pola pita yang berbeda sehingga dapat dibedakan satu sama lain.

$$
D=1-C
$$

C didefinisikan sebagai probabilitas ketidakpastian :

$$
C=\sum C_{i}=\sum p_{i} \frac{N_{p i}-1}{N-1}
$$

Daya diskriminan digunakan sebagai solusi atas tingkat kebingungan ataupun ketidakpastian yang muncul saat pembacaan pola pita (Tessier et al., 1999). Nilai terbesar D adalah 1, yang bermakna bahwa tidak terdapat keraguan atas pola pita yang terbaca. Oleh karena itu, nilai D sering digunakan untuk melihat efesiensi suatu penanda.

Nilai daya bagi (resolving power $/ R$ ) merupakan nilai yang menunjukkan kemampuan pembacaan penanda dalam membedakan alel-alel pada studi yang dilakukan :

$$
R=\sum I_{b}
$$

$I_{b}$ atau nilai informatif pita berkisar antara $0-1$, dan $I_{b}=1-(2 x|0,5-p|), \mathrm{p}$ merupakan bagian dari sampel yang berisi pita yang diamati (Amiryousefi et al., 2018). Nilai R menunjukkan keefektifan pembacaan pola pita digunakan untuk analisis. Nilai ini dapat digunakan untuk membandingkan keefektifan cara baca pola pita dengan studi/penelitian penanda genetik lainnya.

\section{HASIL DAN PEMBAHASAN}

Diaphorase $\quad$ (E.C.1.6.4.3). Hasil elektroforesis menunjukkan bahwa enzim Diaphorase menghasilkan pola pita yang paling terang dibandingkan dengan kedua sistem enzim lainnya yang membentuk warna yang lebih pekat. Pembacaan pola pita Diaphorase tidak membutuhkan pencahayaan khusus. Pewarnaan sistem enzim Diaphorase menunjukkan adanya 10 pola pita isozim (Gambar 2). Pola pita Diaphorase yang teramati memiliki nilai Rf, 0,$26 ; 0,3 ; 0,36 ; 0,43 ; 0,47 ; 0,51 ; 0,54 ; 0,63$; 0,72 ; dan 0,78 (Gambar 3). Terdapat 2 pola pita yang terdapat pada seluruh sampel trembesi yang digunakan, yaitu pola pita dengan nilai $\mathrm{Rf}$ 0,36 dan 0,47 . Sebagai penanda yang bersifat kodominan, pola pita isozim yang terbentuk dari sistem enzim Diaphorase dikelompokkan menjadi tiga lokus.

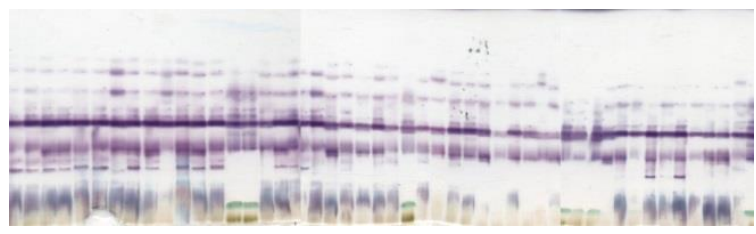

Gambar 2. Profil pola pita Diaphorase

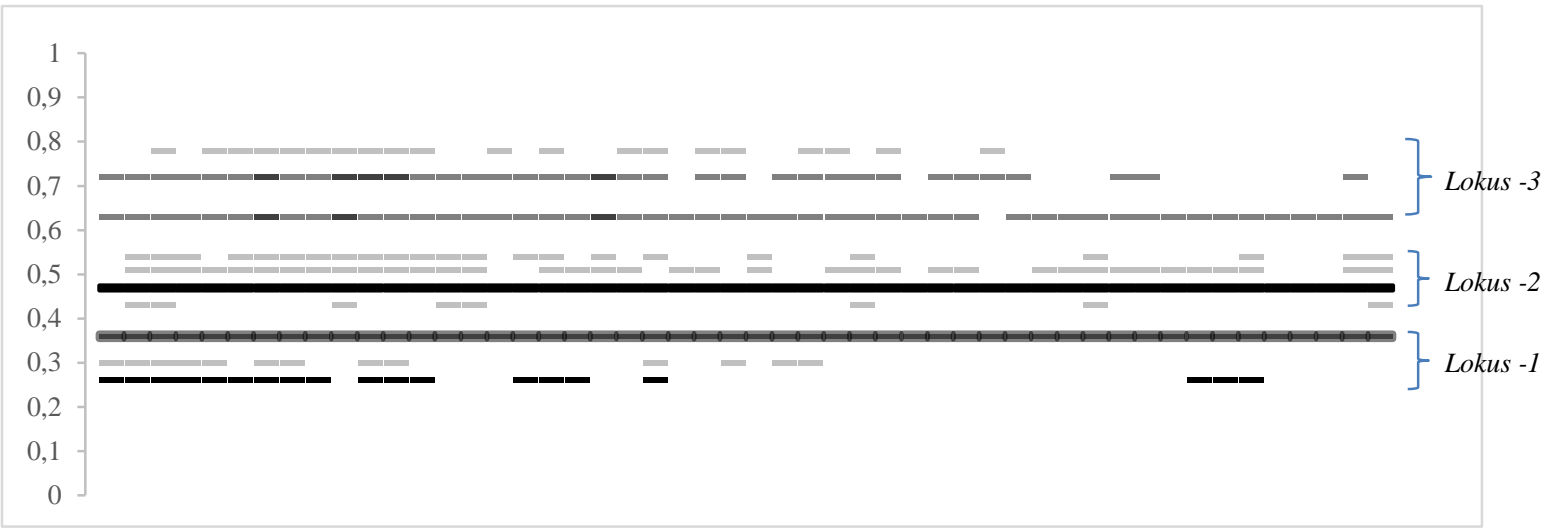

Gambar 3. Zymogram pola pita Diaphorase

Esterase (EC.3.1.1.). Pewarnaan sistem enzim Esterase menunjukkan warna yang paling pekat diantara kedua sistem enzim lainnya (Gambar 4). Upaya membaca pola pita yang terbentuk di dalam gel memerlukan pencahayaan yang khusus agar setiap pola pita dapat dibaca dengan jelas. Pola pita yang terbentuk sebanyak 9 pola, dengan nilai Rf 0,31 ; 
0,$34 ; 0,38 ; 0,5 ; 0,55 ; 0,58 ; 0,65 ; 0,70 ;$ dan 0,74 .

Terdapat 1 pola pita yang muncul pada seluruh sampel, yaitu pola pita dengan nilai $\operatorname{Rf} 0,34$. Pola yang terbentuk dikelompokkan ke dalam 3 lokus.

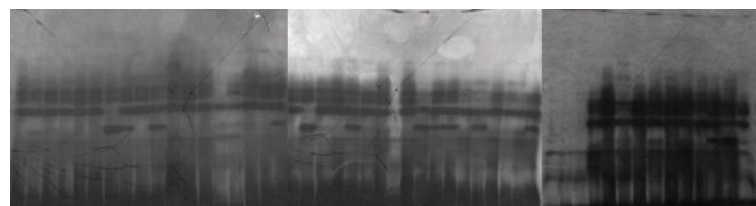

Gambar 4. Profil pola pita Esterase

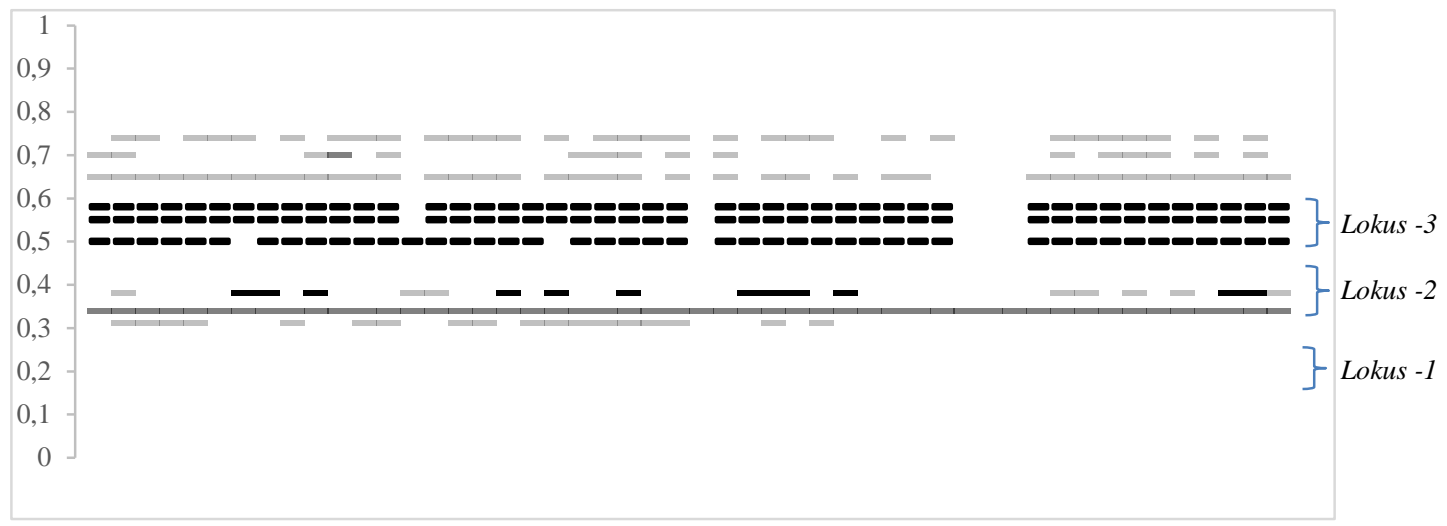

Gambar 5. Zymogram pola pita Esterase

Peroxidase (EC.1.11.1.7). Terdapat 4 pola pita yang terbaca dengan bantuan pencahayaan pada sistem enzim Peroxidase. Nilai Rf dari keempat pola tersebut yaitu, 0,26; 0,$30 ; 0,45$; dan 0,48 . Diantaranya terdapat 2 pola pita yang dapat ditemukan pada seluruh sampel, yaitu pola pita yang memiliki nilai Rf.
0,26 dan 0,30. Pola pita yang terbentuk di kelompokkan ke dalam 2 lokus.

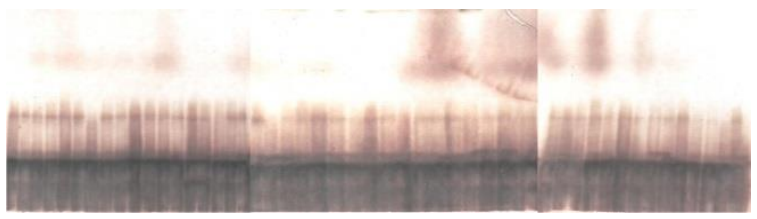

Gambar 6. Profil pola pita Peroxidase

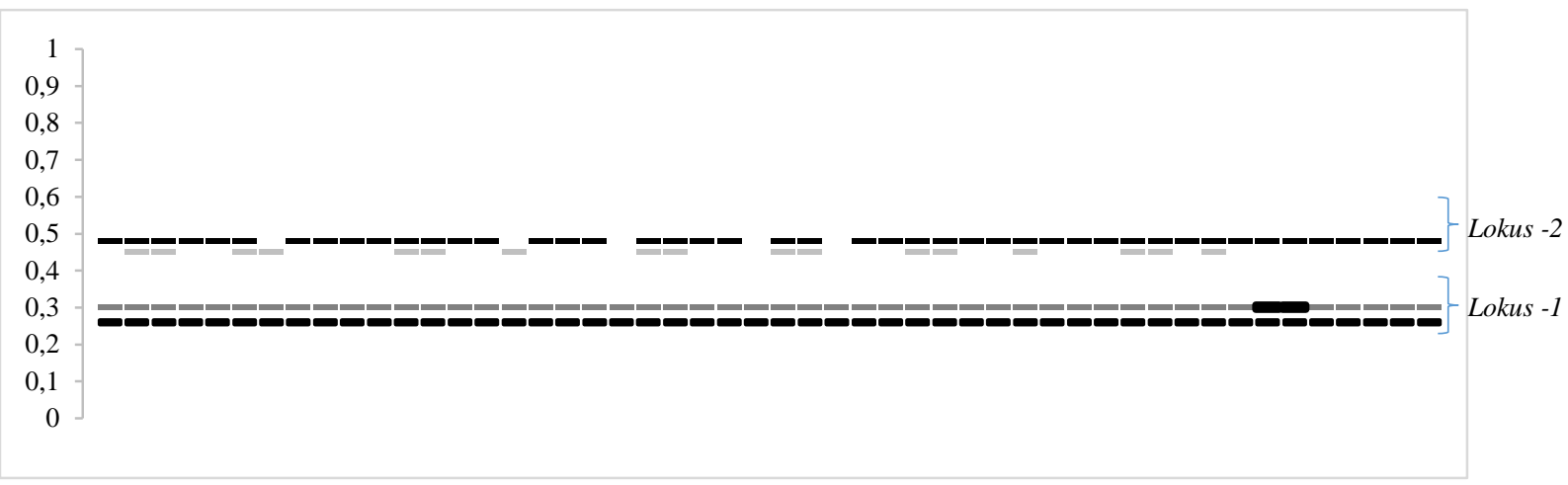

Gambar 7. Zymogram pola pita Peroxidase

Wendel \& Weeden (1989) menyatakan bahwa pola pita yang terbentuk setelah elektroforesis disebut dengan fenotipe elektroforesis. Untuk keperluan studi genetika, fenotipe tersebut perlu diterjemahkan kedalam genotipe-genotipe berdasarkan setiap lokus yang terbentuk. Syah \& Arbain (2017) menerjemahkan alel-alel yang terbentuk ke dalam lokus dan memberinya kode sebagai DIA-1, DIA-2, dan DIA-3 untuk Diaphorase, serta EST-1, EST-2, dan EST-3 untuk Esterase. Pada Peroxidase hanya satu lokus yang dapat digunakan dalam analisis genetik, yaitu POD, mengingat salah satu lokus yang terbentuk berupa pola pita monomorfik, sedangkan analisis keragaman genetik memerlukan pola pita yang polimorfik.

Analisis pola pita isozim yang terbentuk dari hasil penelitian dan dihitung menggunakan iMEC: online marker efficiency calculator 
(Amiryousefi et al., 2018) menunjukkan nilainilai yang ditunjukkan pada Tabel 1. Dari polapola pita yang terbentuk dapat diketahui bahwa $80 \%$ pola pita Diaphorase, $88 \%$ pola pita Esterase, dan $50 \%$ pola pita Peroxidase bersifat polimorfik. Polimorfisme digunakan sebagai dasar analisis pola-pola pita yang terbentuk karena adanya polimorfisme memungkinkan dilakukannya identifikasi terhadap alel-alel yang terdapat pada setiap lokus sebagai suatu alternatif yang dapat digunakan untuk mengenali atau menandai gen dalam upaya melakukan penelitian terkait dengan genetika. Terlebih lagi elektroforesis protein sebagai dasar dari analisis isozim dapat digunakan untuk mendeteksi perbedaan alel-alel yang bersifat homosigot maupun heterosigot (Singh \& Kulathinal, 2013).

Nilai $\mathrm{H}$ terendah adalah 0 dan tertinggi adalah 1, yang bermakna bahwa jika suatu populasi tanaman berada pada kondisi setimbang, sesuai dengan Hardy-Weinberg equilibrium (HWE) maka seluruh genotipe tanaman tersebut bersifat heterosigot jika berada pada nilai tertinggi dan bersifat homosigot jika berada pada nilai terendah (Freeland, 2005). Nilai $\mathrm{H}$ yang diperoleh dari hasil penelitian berkisar antara 0,307 - 0,475 yang menunjukkan bahwa proporsi genotipe homosigot lebih besar daripada genotipe heterosigot. Nilai PIC berkisar antara 0,260 - 0362 yang menunjukkan proporsi genotipe heterosigot induk yang diturunkan kepada keturunannya. Nagy et al. (2012) menyatakan bahwa PIC adalah modifikasi dari nilai heterozigositas sebagai sebuah pendugaan bahwa terdapat individuindividu yang tidak memberikan informasi genetik pada turunannya (linkage analysis).

Rasio E menunjukkan nilai antara 3,24 6,16 , menunjukkan bahwa tidak seluruh pola pita polimorfik efektif untuk disertakan ke dalam analisa. Untuk Diaphorase hanya terdapat 6 pola pita polimorfik yang efektif untuk dianalisa keragaman genotipe-nya dari 8 pola pita polimorfik yang terbaca. Untuk Esterase, hanya terdapat 6 pola pita dari 9 pola pita polimorfik yang efektif untuk analisa. Sedangkan, Peroxidase terdapat 3 pola pita dari 4 pola pita polimorfik yang efektif digunakan untuk analisa. Berdasarkan nilai PIC dan E, maka dapat ditentukan besarnya MI. Nilai MI terbesar terdapat pada Esterase, terendah adalah Peroxidase. Selisih MI Esterase dan Diaphorase relatif sangat kecil, sehingga dapat disimpulkan bahwa dari ketiga sistem enzim yang digunakan, Esterase dan Diaphorase merupakan penanda yang memiliki efisiensi lebih baik dibandingkan dengan Peroxidase. Kombinasi nilai antara PIC, E, dan MI dapat digunakan untuk mengetahui penanda terbaik yang dapat digunakan dalam analisis keragaman genetik. Samriti et al. (2017) dalam penelitiaannya pada jenis Rubus ellipticus juga menemukan bahwa nilai PIC, E dan MI dapat digunakan dalam menentukkan primer terbaik yang digunakan dalam penelitiaannya menggunakan penanda ISSR (Inter simple sequence repeat).

Tabel 1. Tabel parameter polimorfisme penanda isozim trembesi di Sangatta

\begin{tabular}{clcccccccc}
\hline No. & Penanda isozim & Jumlah iita & $\begin{array}{c}\text { Jumlah pita } \\
\text { polimorfik }\end{array}$ & $\mathbf{H}$ & PIC & E & MI & D & R \\
\hline 1 & Diaphorase & 10 & 8 & 0,475 & 0,362 & 6,1 & 2,21 & 0,63 & 4,44 \\
2 & Esterase & 9 & 8 & 0,4319 & 0,338 & 6,16 & 2,08 & 0,53 & 4,00 \\
3 & Peroxidase & 4 & 2 & 0,307 & 0,260 & 3,24 & 0,84 & 0,34 & 0,88 \\
\hline
\end{tabular}

Keterangan: $\mathrm{H}=$ heterosigositas harapan; $\mathrm{PIC}=$ polymorphism information content $\mathrm{E}=$ Effective multiplex ratio $; \mathrm{MI}=$ Marker index $; \mathrm{D}=$ Discriminating power $; \mathrm{R}=$ Resolving power

Nilai D tertinggi terletak pada Esterase $(0,63)$, dan terendah adalah Peroxidase $(0,34)$. Nilai tersebut menunjukkan bahwa pembacaan pola pita paling rumit dan menimbulkan keraguan terdapat pada Peroxidase, sedangkan pembacaan pola pita paling mudah terdapat 
pada Diaphorase. Nilai $\mathrm{R}$ juga menunjukkan bahwa Diaphorase merupakan penanda yang paling efektif dibandingkan yang lainnya. Dari seluruh parameter yang dinilai, Diaphorase menunjukkan konsistensi terhadap penilaian yang dilakukan. Dalam studi ini dapat disimpulkan bahwa penanda isozim terbaik untuk jenis trembesi adalah sistem enzim Diaphorase.

Parameter-parameter genetik di atas menunjukkan bahwa penanda isozim yang diujikan pada penelitian ini dapat digunakan untuk analisis keragaman genetik pada trembesi. Di Indonesia penggunaan penanda isozim untuk analisa keragaman genetik jenis-jenis pohon telah lama dilakukan, diantaranya pada sengon (Seido et al., 1993), jati (Kertadikara \& Prat, 1995), tusam (Indrioko \& Na'iem, 1997), meranti (Na'iem, 2001; Sudarmonowati et al., 2001), merbau (Yudohartono, 2008), eboni (Kinho et al., 2016), ulin (Sudarmonowati et al., 2001), cendana (Haryjanto, 2009), kayu putih (Wulandari, 2007), jelutung (Wahyudiningsih et al., 2015). Isozim juga digunakan sebagai penanda genetik jenis-jenis pohon penghasil buah-buahan, diantaranya adalah durian (Salasa, Ashari, \& Herlina, 2013), nangka (Adelina et al., 2006), kelapa (Hengky et al., 1988), aren (Haryjanto et al., 2011). Jenis-jenis pohon tersebut merupakan pohon-pohon yang dibudidayakan untuk tujuan produksi. Rao \& Hodgkin (2002) menyatakan bahwa data-data yang diperoleh dari analisis keragaman genetik pada umumnya digunakan untuk memastikan taksonomi jenis tertentu, asal-usul tanaman dan laju evolusinya, dan seleksi untuk pertanaman dan konservasi.

\section{KESIMPULAN}

Diaphorase menunjukkan konsistensi yang tinggi terhadap parameter-parameter genetik dibandingkan dengan sistem enzim yang lain. Berdasarkan hasil tersebut, sistem enzim terbaik yang dapat digunakan untuk menganalisa keragaman pola pita trembesi adalah Diaphorase. Esterase dapat digunakan sebagai alternatif penanda, sedangkan Peroxidase selalu menunjukkan nilai terendah pada parameter-parameter yang dinilai. Dengan diketahuinya pola pita tersebut, analisis keragaman genetik pada trembesi dapat dilakukan dan informasinya digunakan sebagai pertimbangan dalam pemanfaatan trembesi sebagai tanaman konservasi maupun produksi.

\section{UCAPAN TERIMA KASIH}

Terima kasih penulis sampaikan yang sebesar-besarnya kepada Kemenristekdikti yang telah membiayai penelitian ini dalam skema penelitian dosen pemula yang dilaksanakan pada tahun 2017 (surat DRPM No.: 1444/E3/LT/2017). Analisis laboratorium dapat dilaksanakan atas bantuan Dr. Sapto Indrioko, S.Hut., MP dan sdr. Untung Maryanto dari Laboratorium Pemuliaan Pohon, Fakultas Kehutanan Universitas Gadjah Mada. Dukungan administratif sepenuhnya dibimbing oleh Alm. Dr. Sugiarto, S.Hut., M.Agr. dari STIPER Kutai Timur.

\section{DAFTAR PUSTAKA}

Adelina, E., Tambing, Y., Budiarti, T., \& Murniati, E. (2006). Identifikasi Keragaman Kultivar Nangka Berdasar Ciri Morfologi dan Analsis isoenzim. Jurnal Agrisains, 7(3), 150-155.

Amiryousefi, A., Hyvönen, J., \& Poczai, P. (2018). iMEC: Online Marker Efficiency Calculator. Applications in Plant Sciences, 6(6), 4-7. https://doi.org/10.1002/aps3.1159

CABI. (2016). Samanea Saman. In: Invasive Species Compendium. Wallingford, UK: CAB Internationa.

Chesnokov, Y. V., \& Artemyeva, A. M. (2015). Evaluation of the measure of polymorphism information of genetic diversity. Sel'skokhozyaistvennaya Biologiya, 50(5), 571-578.

https://doi.org/10.15389/agrobiology.2015.5. 571eng

Dahlan, E. N. (2008). Jumlah emisi gas CO2 dan pemilihan jenis tanaman berdaya rosot sangat tinggi: studi kasus di Kota Bogor. Media Konservasi Agustus, 13(2), 85-89.

Freeland, J. R. (2005). Molecular Ecology. John Wiley \& Sons Ltd. 
Haryjanto, L. (2009). Keragaman genetik cendana (Santalum album Linn) di kebun konservasi ex situ Watusipat, Gunungkidul, dengan penanda isosim. Jurnal Pemuliaan Tanaman Hutan, 3(3), 127-138. https://doi.org/10.20886/jpth.2009.3.3.127138

Haryjanto, L., Prastyono, P., \& Ismail, B. (2011). Keragaman genetik empat populasi Arenga pinnata merr berdasarkan penanda isozim. Jurnal Pemuliaan Tanaman Hutan, 5(1), 1321. https://doi.org/10.20886/jpth.2011.5.1.1321

Hengky, N., Hartana, A., \& Gadrinab, L. U. (1988). Keanekaragaman pola pita isozim peroksidase pada koleksi kelapa di Kebun Percobaan Pakuwon Sukabumi. Flotibunda, 1(7), 25-28.

\section{KEMENTERIAN SEKRETARIAT NEGARA} REPUBLIK INDONESIA. (2010). Sambutan Pengantar Presiden RI pada Peringatan Hari Menanam Pohon Indonesia, 28-11-2010 | Sekretariat Negara.

Kertadikara, A. W. S., \& Prat, D. (1995). Isozyme variation among teak (Tectona grandis L.f.) provenances. Theoretical and Applied Genetics, 90(6), 803-810. https://doi.org/10.1007/BF00222015

Kinho, J., Na'iem, M., \& Indrioko, S. (2016). Studi keragaman genetik Diospyros rumpii Bakh di Sulawesi Utara berdasarkan penanda isoenzim. Jurmal Pemuliaan Tanaman Hutan, 10(2), 95-109. https://doi.org/10.20886/jpth.2016.10.2.95109

Markert, C. L., \& Moller, F. (1959). Chemical,5' 6, 7. Science, 45, 753-763.

Na'iem, M. (2001). Genetic Variations Of Shorea Leprosula Miq. In Three Populations In Indonesia: Implication For Exsituconservation. Buletin Kehutanan=Forestry Bulletin, O(2001).

Nagy, S., Poczai, P., Cernák, I., Gorji, A. M., Hegedüs, G., \& Taller, J. (2012). PICcalc: An online program to calculate polymorphic information content for molecular genetic studies. Biochemical Genetics, 50(9-10), 670-672. https://doi.org/10.1007/s10528012-9509-1

Novi Salasa, K. A., Ashari, S., \& Herlina, N. (2013). Identifikasi tanaman durian (Durio zibethinus Murray) mirip durian varietas bido di Kecamatan Wonosalam Kabupaten Jombang dengan metode isozim dan morfologi. Jurnal
Produksi Tanaman, 1(5). https://doi.org/10.21176/PROTAN.V1I5.54

Ramanatha Rao, V., \& Hodgkin, T. (2002). Genetic diversity and conservation and utilization of plant genetic resources. Plant Cell, Tissue and Organ Culture, 68(January), 1-19. https://doi.org/10.1023/A:1013359015812

Samriti, Kaur, R., Shilpa, S., Malhotra, E. V., Poonam, P., Thakur, D., \& Kumar, K. (2017). Assessment of genetic diversity in rubusellipticus (Smith) using molecular markers. Proceedings of the Indian National Science Academy, 83(3), 669-679. https://doi.org/10.16943/ptinsa/2017/49120

Sapto Indrioko, M. N. (1997). Variasi isozim pada hutan tanaman Pinus merkusii Jungh. et de Vriese di Jawa=Isozyme Variation of Pinus Merkusii fungh. et de Vriese. Berkala Penelitian Pasca Sarjana, 10(1997).

Seido, K., Widyatmoko, A. Y. P. B. C., \& Nursinggih, G. (1993). Genetic variation at four allozyme loci in Paraserianthes falcataria at Wamena in Irian Jaya.

Singh, R. S., \& Kulathinal, R. J. (2013). Polymorphism. Brenner's Encyclopedia of Genetics: Second Edition, 3, 398-399. https://doi.org/10.1016/B978-0-12-374984$0.01189-\mathrm{X}$

Staples, G. W., \& Elevitch, C. R. (2006). Samanea saman (rain tree). Species Profiles for Pacific Island Agroforestry, April, 15. https://www.researchgate.net/publication/311 667816_Samanea_saman_rain_tree

Sudarmonowati, E., Hartati, N. S., Narendra, B. H., Basyuni, M., Siregar, U. J., \& Iriantono, D. (2001). Genetic Markers for Assessing Genetic Diversity and Improvement of Several Tropical Forest Tree Species to Support Conservation Program. Proceedings of the International Conference on Ex Situ and in Situ Conservation of Commercial Tropical Trees, 355-369.

Sulkowska, K. M. (2012). Isoenzyme Analyses Tools Used Long Time in Forest Science. In Electrophoresis. InTech. https://doi.org/10.5772/45756

Syah, T. H., \& Arbain, A. (2017). Prosiding Seminar Nasional Variasi Isozim Pohon Trembesi Yang Berpotensi Invasif di Sangatta, Kutai Timur, Kalimantan Timur.

Tessier, C., David, J., This, P., Boursiquot, J. M., \& Charrier, A. (1999). Optimization of the choice of molecular markers for varietal identification in Vitis vinifera L. Theoretical 
and Applied Genetics, 98(1), 171-177. https://doi.org/10.1007/s001220051054

Wahyudiningsih, T. S., Naiem, M., Indrioko, S., \& Sumardi, I. (2015). Allozyme variation of the endemic and vulnerable Dyera lowii Hook.f. in Central Kalimantan: Implications for genetic resources conservation. Indonesian Journal of Biotechnology, 19(1), 79. https://doi.org/10.22146/ijbiotech.8637

Wendel, J. F., \& Weeden, N. F. (1989). Visualization and Interpretation of Plant Isozymes.
Isozymes in Plant Biology, 5-45. https://doi.org/10.1007/978-94-009-1840-5_2

Wulandari, Agustina, R., \& Taryono. (2007). Pendugaan tingkat silang dalam pohon kayu putih Melaleuca cajuputi dengan penanda Isozim.

Yudohartono, T. P. (2008). Variasi genetik beberapa populasi merbau (Intsia bijuga O. Ktze) berdasarkan penanda isoenzim. Jurmal Pemuliaan Tanaman Hutan, 2(3), 243-251. https://doi.org/10.20886/jpth.2008.2.3.243251 
J urnal Pemuliaan Tanaman Hutan

Vol. 14 No. 2, Desember 2020, p. 141 - 149 